\title{
Investigation of the decomposition and leaching dynamics of Salix, Populus and mixed leaves in the area of Lake Balaton and Kis-Balaton Wetland
}

\author{
Brigitta Simon - Tamás Kucserka - Angéla Anda \\ Department of Meteorology and Water Management, University of Pannonia, Keszthely, Hungary \\ simonbrigitta.georgikon@gmail.com
}

\begin{abstract}
SUMMARY
In lakes and wetlands, leaf litter input from the coastal vegetation represents a major nutrient load and plays a basic structural and functional role in several ecosystems. In Hungary, at the banks of lakes and wetlands, Salix and Populus trees are the most common species. In an experiment in Lake Balaton and Kis-Balaton Wetland between 16 November 2017 to and 3 June 2018, the decomposition rates and leaching dynamics of Salix, Populus and mixed leaves (50\% Salix and 50\% Populus) were investigated. Total nitrogen and phosphorus content of biomass samples were measured at the beginning and end of the experiment for the leaching dynamics experiment. We found that litter mass losses (Salix, Populus and mixed leaves) were not significantly different between the two mesh size litterbags and between Lake Balaton and Kis-Balaton Wetland. Different amounts of the total nitrogen and phosphorus leaching from Salix, Populus and mixed leaves were detected. The total nitrogen contents of the plant samples were around 8-18\% at the end of the investigated period. Slightly higher values were measured compared to phosphorous (27-29\%).
\end{abstract}

Keywords: leaf litter decomposition, leaching, Lake Balaton, Kis-Balaton Wetland, Salix, Populus

\section{INTRODUCTION}

On 23 October 2000, the "Directive 2000/60/EC of the European Parliament and of the Council establishing a framework for the Community action in the field of water policy" or, in short, the EU Water Framework Directive (WFD) was finally adopted (DIRECTIVE 2000/60/EC OF THE EUROPEAN PARLIAMENT AND OF THE COUNCIL). The aim of the directive is to reach a "good" overall quality of all waters. The directive, extending to 27 countries, initiated an important trend towards an ecosystembased approach for water policy and water resource management (Kallis and Butler, 2001).

Deciduous leaf litter is a main energy source for the food webs in fresh water ecosystems (Fisher et al., 1973). The decomposition dynamics of leaves depend on abiotic factors such as flow, temperature, physical abrasion (Petersen and Cummins, 1974), pH (Faye, 2006), nitrate and phosphate concentrations (Pozo, 1993), and biotic factors such as initial litter quality (Melillo et al., 1984), invertebrates and microbial colonization (Abelho, 2008). The decomposition process can be affected by changes in biodiversity at various levels including species richness of microbial communities (Duarte et al., 2006), detritivorous invertebrates (Schälder and Brandl, 2005), and plant litter itself (Kominoski et al., 2007).

Leaf flitter decomposition is a very long, multistage, complicated process. After the leaf enters the water, it will lose up to $25 \%$ of its dry mass due to the release of its water-soluble compounds during the first 24 hours in the aquatic environment (Webster and Benfield, 1986). At this time polyphenols and carbohydrates are mainly dissolved in the water (Suberkropp and Klug, 1976). The presence of different leaves accelerates decomposition processes.

The aim of study were to investigate (1) the decomposition rates of the most common leaves (Salix,
Populus) in the area of Lake Balaton and Kis-Balaton Wetland and (2) the changes in nitrogen and phosphorous contents in detritus.

\section{MATERIAL AND METHODS}

\section{Physical and chemical variables of the water}

Water samples were taken from 16 November 2017 to 3 June 2018 every second week by a telescopic water sampler. The water samples were $\mathrm{pH}$, conductivity (Neotek-Ponsel Odeon), $\mathrm{PO}_{4}^{-}, \mathrm{NH}_{4}{ }^{+}, \mathrm{NO}_{3}{ }^{-}, \mathrm{SO}_{4}{ }^{2-}, \mathrm{Cl}^{-}$ determined in the laboratory (Lovibond MultiDirect photometer). Water temperature measurement was continuous on site from November to June (DeltaOhm HD 2-221). T-tests with a significance level of 5\% (Microsoft Office Excel 2016) were used to process data.

\section{Investigation of the leaf litter decomposition}

The study was conducted in Lake Balaton and KisBalaton Wetland. Leaf litter decomposition rates of Salix, Populus and mixed leaves (50\% Salix and 50\% Populus) were studied using the commonly applied litter bag technique (Bärlocher et al., 2005). The experiment was carried out from 16 November 2017 to 3 June 2018. Leaf litter was air-dried until constant dry weight before the experiment. Samples of leaf litter were collected from Lake Balaton and Kis-Balaton Wetland in October 2017. Leaf litter was transferred into litter bags with the size of $10 \times 10 \mathrm{~cm}$ with two mesh sizes of $3 \mathrm{~mm}$ (large) and $900 \mu \mathrm{m}$ (small). The litter bags were positioned on 16 November 2017 at the water-sediment interface of the experimental area to plastic crates. Three litter bags of each species were retrieved after 14, 112, 126, 140, 153 and 158 days. Plant material was transported to the laboratory and cleaned with tap water. After that, litter was washed using tap water, then air-dried to constant weight. 
Litter decomposition rates (exponential decay coefficient, $k$ ) were calculated according to the traditional exponential formula (Jenny et al., 1949; Olson, 1963; Petersen and Cummins, 1974; Bärlocher et al., 2005). Based on the k-value, decomposition rate can be classified as fast, medium and slow.

Leaf mass losses (Lake Balaton and Kis-Balaton Wetland, in large and small mesh size litterbags) were compared using t-test with a significance level of $5 \%$.

\section{Investigation of the leaching dynamics}

The leaching dynamics of Salix, Populus and mixed leaves (50\% Salix and 50\% Populus) were studied from 16 November 2017 to 23 April 2018. Release of nutrients during decomposition of the leaf litter was investigated in situ in Lake Balaton and Kis-Balaton Wetland using 0.5 liter of volume glass bottles into which 0.45 liter of distilled water and $10 \mathrm{~g}$ of oven dried leaf litter material were placed (Gaudet and Muthuri, 1981). The bottles were incubated into the water to $1 \mathrm{~m}$ depth at natural temperatures. The changes in nutrient content of each bottle were analyzed after 7, 14, 32, 48, $60,74,123,144$ and 158 days by taking $450 \mathrm{ml}$ of water from the triplicates for the determination of total nitrogen and total phosphorus (Lovibond MultiDirect). Total nitrogen and total phosphorus contents of Salix, Populus and mixed leaves were determined at the beginning and end of the experiment. Leaching dynamics were compared using t-test with a significance level of $5 \%$.

\section{RESULTS AND DISCUSSION}

\section{Water quality}

The physical and chemical variables of the water samples from Lake Balaton and Kis-Balaton Wetland are shown in Table 1. There was a significant difference between the $\mathrm{pH}$ values of the two sampling sites $(\mathrm{P}<0.05)$, the $\mathrm{pH}$ was higher in Lake Balaton, than in Kis-Balaton Wetland. The decrease in $\mathrm{pH}$ can be explained by the presence of organic acids in water (Gaudet and Muthuri, 1981). There was no significant difference in conductivity $(\mathrm{P}=0.3695)$ and water $(\mathrm{P}=0.7685)$ temperature between the two sampling points.

Changes in the main physical and chemical parameters of water in Lake Balaton and Kis-Balaton Wetland

\begin{tabular}{|c|c|c|c|c|c|c|c|c|}
\hline & $\begin{array}{c}\text { Water } \\
\text { temperature } \\
{ }^{\circ} \mathrm{C} \\
\end{array}$ & $\mathrm{pH}$ & $\begin{array}{l}\text { Conductivity } \\
\left(\mu \mathrm{S} \mathrm{cm}^{-1}\right)\end{array}$ & $\begin{array}{c}\mathrm{NO}_{3}^{-} \\
\left(\mathrm{mg} \mathrm{l}^{-1}\right)\end{array}$ & $\begin{array}{c}\mathrm{NH}_{4}{ }^{+} \\
\left(\mathrm{mg} \mathrm{l}^{-1}\right) \\
\end{array}$ & $\begin{array}{l}\mathrm{SO}_{4}^{2-} \\
\left(\mathrm{mg} \mathrm{l}^{-1}\right) \\
\end{array}$ & $\begin{array}{c}\mathrm{PO}_{4}{ }^{3-} \\
\left(\mathrm{mg} \mathrm{l}^{-1}\right) \\
\end{array}$ & $\begin{array}{c}\mathrm{Cl}^{-} \\
\left(\mathrm{mg} \mathrm{l}^{-1}\right) \\
\end{array}$ \\
\hline $\begin{array}{l}\text { Lake Balaton } \\
\text { Kis-Balaton }\end{array}$ & $8.8 \pm 5.74$ & $8.3 \pm 0.29$ & $677.8 \pm 134.0$ & u.r. & $0.77 \pm 0.35$ & $187.0 \pm 92.80$ & $0.31 \pm 0.20$ & $43.2 \pm 16.45$ \\
\hline Wetland & $8.7 \pm 5.77$ & $7.5 \pm 0.32$ & $758.2 \pm 164.16$ & u.r. & $1.08 \pm 1.17$ & $172.5 \pm 112.55$ & $0.61 \pm 0.35$ & $43.0 \pm 21.76$ \\
\hline
\end{tabular}

The low concentration of $\mathrm{NO}_{3}{ }^{-}$can be explained by the presence of microorganisms and ammoniavolatility (Reddy and Sacco, 1981). Regarding $\mathrm{SO}_{4}{ }^{2-}$ $(\mathrm{P}=0.6247)$ and $\mathrm{Cl}^{-}(\mathrm{P}=0.7242)$ concentrations, there were no significant differences between the two habitats. Kis-Balaton Wetland had higher $\mathrm{NH}_{4}{ }^{+}$ concentrations $\left(1.08 \pm 1.17 \mathrm{mg} \mathrm{l}^{-1}\right)$, than Lake Balaton $\left(0.77 \pm 0.35 \mathrm{mg} \mathrm{l}^{-1}\right)$, the difference was not significant $(\mathrm{P}=0.1705)$. The $\mathrm{PO}_{4}{ }^{3-}$ concentrations of the lake and the wetland were different on a large-scale $(\mathrm{P}=0.0307)$, twice as high in Kis-Balaton Wetland, than in Lake Balaton. The higher $\mathrm{NH}_{4}{ }^{+}$and $\mathrm{PO}_{4}{ }^{3-}$ concentrations can be explained by the succession processes of KisBalaton Wetland.

\section{Leaf mass losses and decomposition coefficients}

After 230 days of incubation, the average remaining dry mass ranged from 42 to $55 \%$ of the initial dry mass depending on litter species and study sites. The mass loss followed a negative exponential pattern during the 230 days of the decomposition period.

Respect of Salix leaf litter, $43 \%-46 \%$ of the initial dry mass remained in the litter bags after 230 days of incubation in Lake Balaton (Figure 1.). The rate was the highest in the large mesh size litterbags. There was no significant difference between the large and small mesh size leaf litter mass losses $(\mathrm{P}=0.1960)$. Changes in dry mass of Populus leaf litter versus time are presented in Figure 1. During the 230 days long study period, leaves lost about the half (54-55\%) of their original mass. We found that litter mass loss was not significantly different between the two mesh size litterbags $(\mathrm{P}=0.8729)$ in Lake Balaton. Mass loss of mixed leaves was $51-52 \%$, which is higher than same values of Salix and lower, than Populus in both types of litterbags. There was no significant difference between the two mesh sizes $(\mathrm{P}=0.7216)$. 


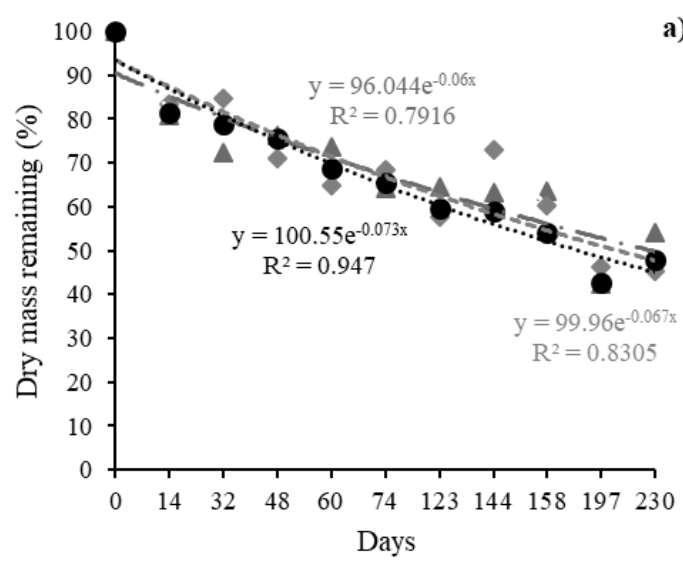

The reduction in the dry weight was the most prominent during the first 14 days in the large $(18 \%)$ and small $(13 \%)$ mesh size litterbags of Salix leaves in Kis-Balaton Wetland (Figure 2.). For Salix, there was no significant difference between the two mesh size litterbags $(\mathrm{P}=0.1553)$ in this water body. After 230 days of incubation in Kis-Balaton Wetland, the remaining Populus (Figure 2.) amount was $47 \%$ in the large mesh size litter bags, whereas in the small mesh size litterbag retained $44 \%$ of its original weight. The dry matter loss of Populus in the Kis-Balaton Wetland was not significantly higher in large mesh size litter bag than small mesh size litter bags $(\mathrm{P}=0.8854)$. Mass loss of mixed leaves was $47-51 \%$ (between Salix and Populus). There was no significant difference between the two mesh sizes $(\mathrm{P}=0.6529)$. Mutch and Davis (1984) used nylon bags of $3.5 \mathrm{~mm}$ and $0.25 \mathrm{~mm}$ mesh to investigate the processing of Salix drummondiana Barratt leaves in Twin Creek and Cabin Creek. Microorganism processing and macroinvertebrate

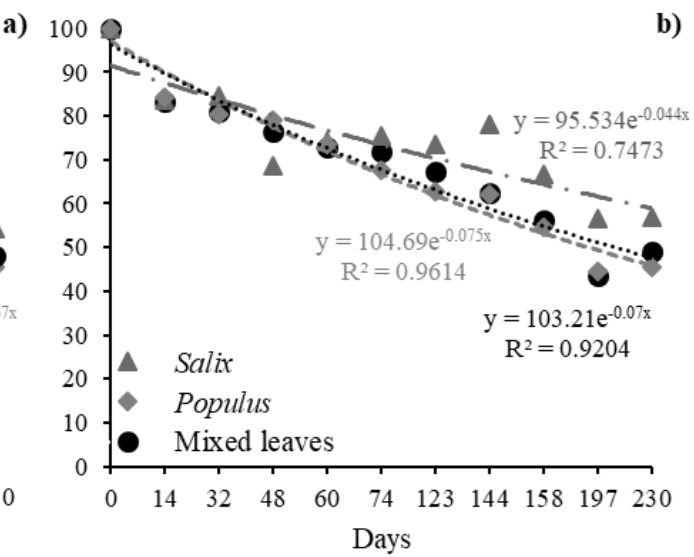

shredding of the leaves were significantly greater in Twin Creek where it was concluded that macroinvertebrate shredding was responsible for $45 \%$ of the weight loss. Most litter mixtures (60-70\%) reviewed by Gartner and Cardon (2004) showed synergistic or antagonistic decomposition rates compared with those estimated from single species. Chapman and Koch (2007) speculated on the possibility that litter mixtures composed of similar species enhance decomposition of each litter species, because a more homogeneous substrate provides greater possibilities for adaptation of the microbial communities, even for specialized decomposers. This is contrary to what we have experienced since we did not find any significant difference between single litter and mixed leaves. Besides plant type, other differences included the environmental conditions and the decomposer community, as the experimental design does not allow us to isolate the plant type effect stricto sensu (Tardif and Shipley, 2014).

Figure 2: The remaining dry mass for Salix, Populus and mixed leaves during the $\mathbf{2 3 0}$ days long experiment in Kis-Balaton Wetland (a - large mesh size litterbag; b - small mesh size litterbag)

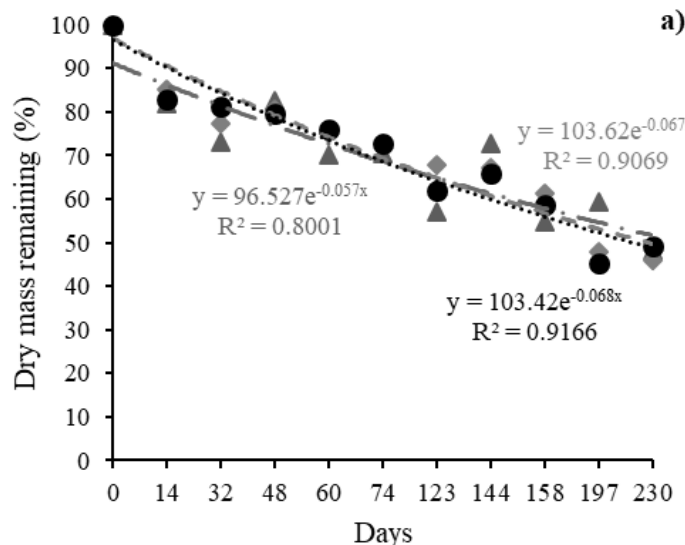

a)

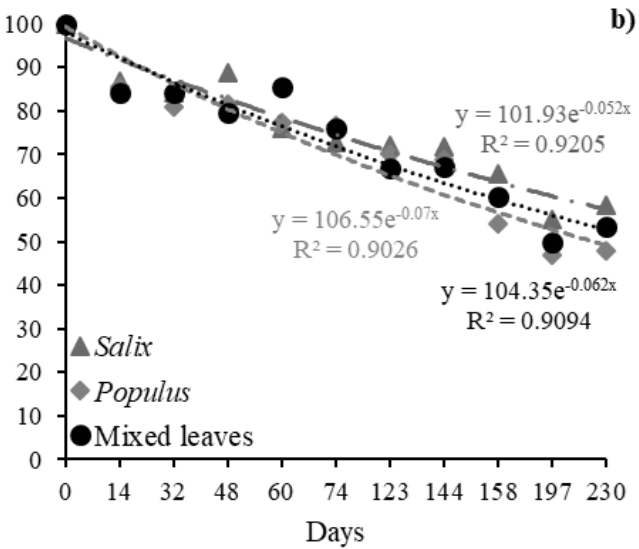


The decomposition of Salix detritus in Lake Balaton and Kis-Balaton Wetland did not show a significant difference between the large $(\mathrm{P}=0.9986)$ and small $(\mathrm{P}=0.7773)$ mesh size litterbags. During our investigation of Populus leaves, the patterns in Lake Balaton and Kis-Balaton Wetland followed an exponential model generating not significant difference between the decomposition rates of detritus in the large $(\mathrm{P}=0.5850)$ and small $(\mathrm{P}=0.6159)$ mesh size litter bags. Comparing Lake Balaton and Kis-Balaton Wetland there was no significant difference between the big $(\mathrm{P}=0.6099)$ and the small $(\mathrm{P}=0.5670)$ mesh size bags filled with mixed leaves. For Salix and Populus, the temporal changes in dry matter were similar between the two study sites, there were not any differences between the two species and mixed leaves throughout. The amount of stem material remaining at the end of the experiment was slightly greater for Salix compared to Populus in the area of Lake Balaton in the large $(\mathrm{P}=0.8583)$ and small $(\mathrm{P}=0.5978)$ mesh size litterbags. In Lake Balaton, there was no significant difference between the mixed and Salix leaves, neither in the big $(\mathrm{P}=0.7825)$, nor in the small $(\mathrm{P}=0.4388)$ mesh size bags. There was also no significant difference between the mixed and Populus leaves, neither in the big $(\mathrm{P}=0.7921)$, nor in the small $(\mathrm{P}=0.9041)$ mesh size bags. In Kis-Balaton Wetland there were no significant differences between the two leaf species in large $(\mathrm{P}=0.6857)$ and small $(\mathrm{P}=0.4636)$ mesh size litterbags. In Kis-Balaton Wetland there was no significant difference between mixed leaves and Salix neither in the big $(\mathrm{P}=0.9577)$, nor in the small $(\mathrm{P}=0.7234)$ mesh size bags. There was also no significant difference between mixed leaves and Populus neither in the big $(\mathrm{P}=0.9199)$, nor in the small $(\mathrm{P}=0.8149)$ mesh size bags.

Figure 3: Decomposition coefficients (k) of Salix, Populus and mixed leaves in Lake Balaton and Kis-Balaton Wetland (mean \pm SD)

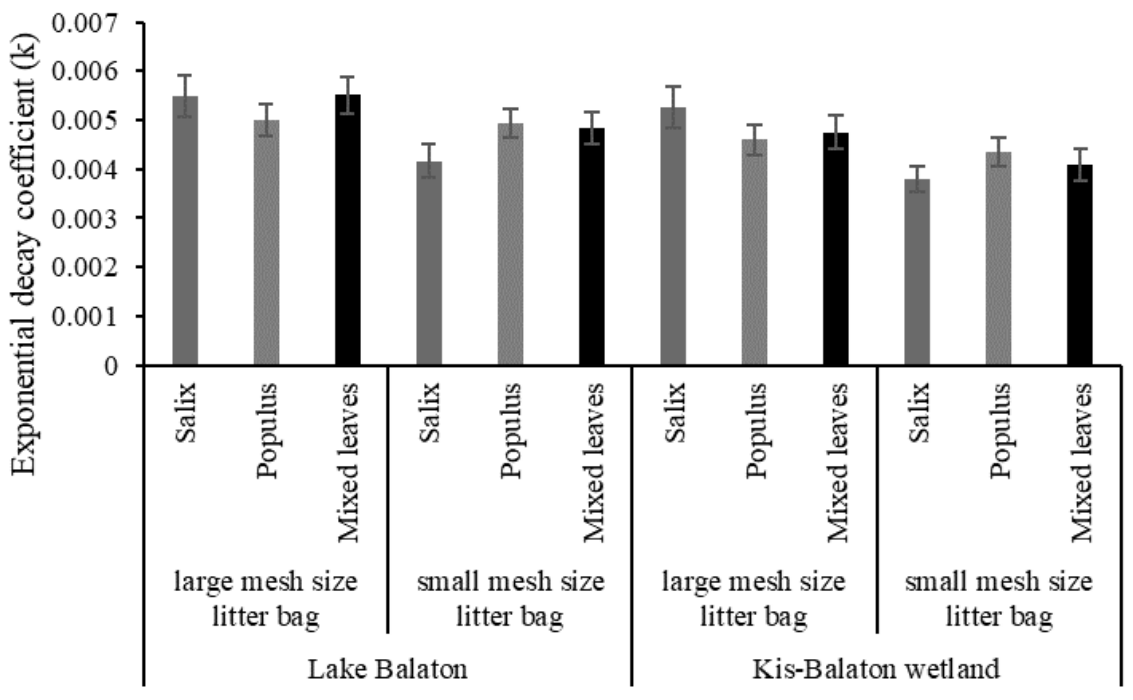

The decomposition rates and the parameters obtained for the adjustment of the exponential model of Salix, Populus and mixed leaves are presented in Figure 3. K-values of mixed leaves were high in Lake Balaton in the small mesh size litterbags $(\mathrm{k}=0.0055)$ and k of Salix was low in Kis-Balaton Wetland in the small mesh size litterbags $(\mathrm{k}=0.0038)$. Salix, Populus and mixed leaves in Lake Balaton in the large mesh size bags and Salix also in the large mesh size bags in KisBalaton Wetland were classified to the medium category. All other samples were in the slow category. In the study of Baldy et al. (1995) the breakdown of Salix, Populus and plane leaves was slow with k ranging from 0.0045 to 0.0091 . For Salix babylonia calculated decay coefficients $(\mathrm{k})$, for 3 and $0.2 \mathrm{~mm}$ mesh bags respectively, were 0.0154 and 0.0114 (Avon River, New Zealand) and 0.0173 and 0.0117 (Cashmere Stream, New Zealand) (Collier and Winterburn, 1986). The Salix decay coefficient $(\mathrm{k}=0.0209)$ for the leaves in Twin Creek, the more typical Rocky Mountain stream, was similar to that reported for the fastest decaying leaves in warmer streams (Mutch and Davis, 1984).

\section{Leaching dynamics}

If the aim is to study decomposition rather than merely leaf breakdown, the metabolism of dissolved matter and fine particulate material lost from the decaying leaf must be addressed as well (Boulton and Bonn, 1991). A growing trend in the total phosphorus concentrations in the bottles was observed (Figure 4). Total phosphorus concentration increased in the first few days. A slow growth in the rest of the studied period was observed. After the 60th day the phosphorus content became stagnant. Significant differences between Salix and Populus $(\mathrm{P}<0.05)$, Salix and mixed leaves $(\mathrm{P}<0.05)$ were found in Lake Balaton. We found that total phosphorus leaching dynamics was not significantly different between Populus and mixed leaves in Lake Balaton $(\mathrm{P}=0.7382)$ and Kis-Balaton Wetland $(\mathrm{P}=0.5127)$. But the total phosphorus leaching dynamics of Salix and Populus $(\mathrm{P}<0.05)$ and Salix and 
mixed leaves $(\mathrm{P}<0.05)$ in Kis-Balaton Wetland show a significant difference. The total phosphorus leaching of Salix $(\mathrm{P}=0.8036)$, Populus $(\mathrm{P}=0.5632)$ and mixed leaves $(\mathrm{P}=0.6548)$ in Lake Balaton and Kis-Balaton Wetland did not show significant differences. The decrease in total phosphorus in plant samples at the end of the study was 28 and 29\% (Salix), Populus 29 and 27\% (Populus), and 27 and 28\% (mixed leaves) in Lake Balaton and Kis-Balaton Wetland, respectively.

Figure 4: The changes in cumulative total phosphorous concentrations in the water of the incubated bottles during the 158 days long experiment period in the area of Lake Balaton (a) and Kis-Balaton Wetland (b)
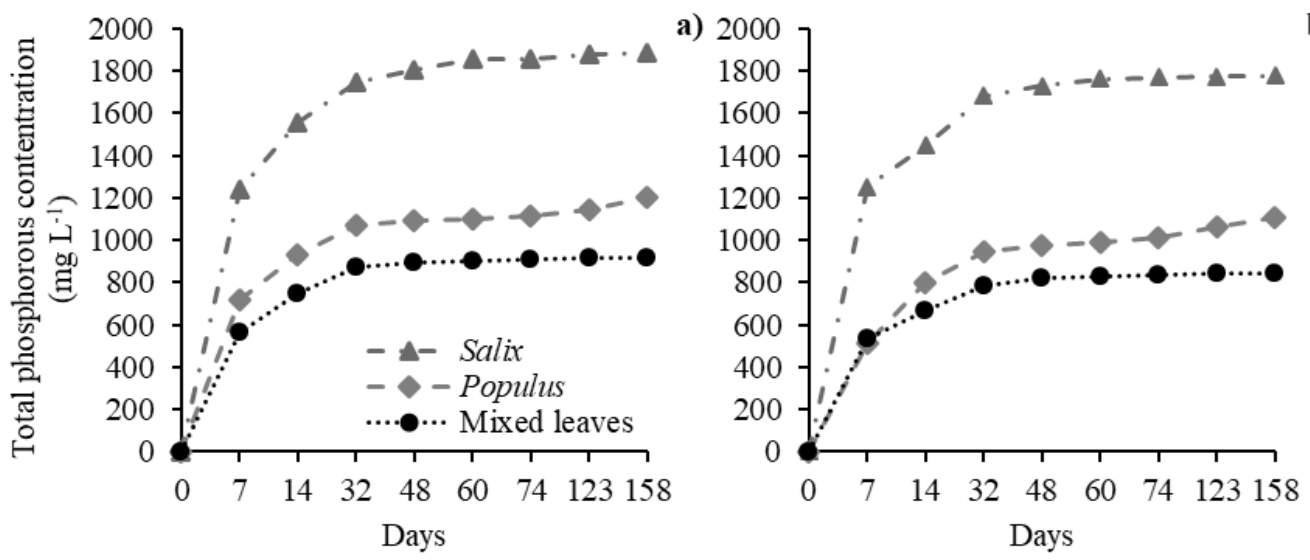

b)

Total nitrogen concentration of water of the incubated bottles increased fast at first (Figure 5), then a slow rise was detected during the $32-158$ days. The total nitrogen leaching dynamics was the highest in Salix and the lowest in the mixed leaves. Between Salix and Populus (Lake Balaton $\mathrm{P}=0.2624$; Kis-Balaton Wetland $\mathrm{P}=0.5739$ ), Salix and mixed leaves (Lake Balaton $\mathrm{P}=0.1011$; Kis-Balaton Wetland $\mathrm{P}=0.5819$ ) and Populus and mixed leaves (Lake Balaton $\mathrm{P}=0.5426$; Kis-Balaton Wetland $\mathrm{P}=0.3254$ ) there were no significant difference. There were no significant difference between Lake Balaton and Kis-Balaton Wetland regarding Salix $(\mathrm{P}=0.7439)$, Populus $(\mathrm{P}=0.5740)$ and mixed leaves $(\mathrm{P}=0.8816)$ in total nitrogen leaching dynamics.

Figure 5: The changes in cumulative total nitrogen concentrations in the water of the incubated bottles during the 158 days long experiment period in the area of Lake Balaton (a) and Kis-Balaton Wetland (b)

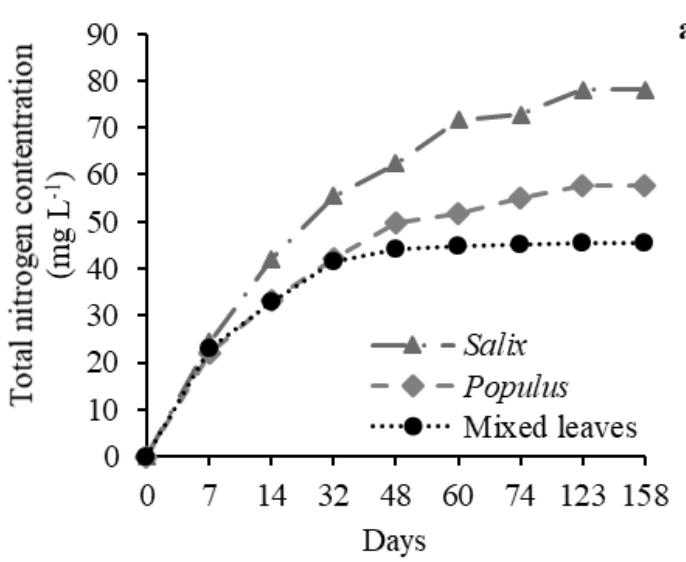

The amount of remaining nitrogen concentration in the plant samples at the end of the experimental period was 82 and $80 \%$ (Salix), 90 and 88\% (Populus) and 92 and $90 \%$ (mixed leaves) in Lake Balaton and KisBalaton Wetland, respectively. Smith and Bradford (2003) found negative interactions when litters of the same species with different initial nitrogen concentrations were mixed. According to Parsons et al.

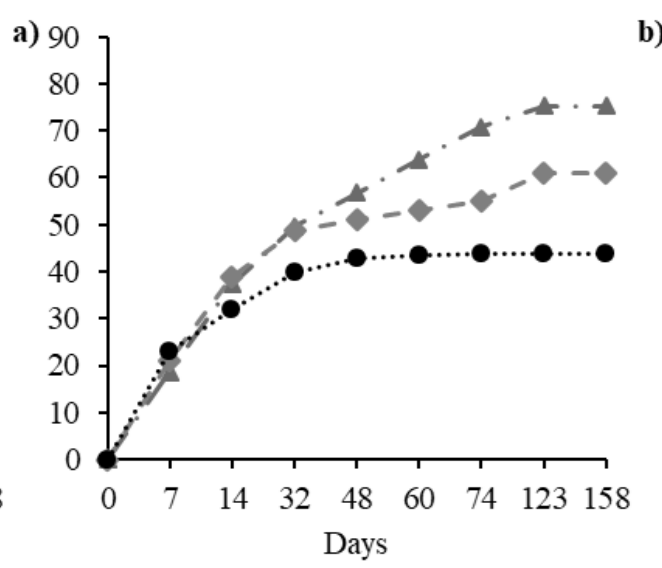

b)

(1990), leaching litter removed substantial quantities of $\mathrm{N}(24 \%)$ and $\mathrm{P}(54 \%)$ and leached leaves still contained $33 \%$ labile (benzene alcohol soluble) material in Populus. 


\section{COCLUSIONS}

Our results show that the mixing of leaf litter does not accelerate - contrary to the literature - the decomposition rates. Despite the different types of water bodies, (lake and wetland) no difference between the decomposition rates was found. This can be explained by the similar physical and chemical properties of the two water bodies. There was no difference in the nitrogen and phosphorous leaching dynamics in Lake Balaton and Kis-Balaton Wetland, which can be explained by the temperature dependence of the dissolution, because the temperature did not differ significantly between the two water bodies. The nitrogen and phosphorus, which get into the water during the leaching, have a basic role on water quality. Leaf litter, falling into the water from the coastal vegetation, contributes to the inner nutrient load of Lake Balaton and Kis-Balaton Wetland. In the long run, the not decomposing plant parts become part of the detritus.

\section{ACKNOWLEDGMENTS}

The publication is supported by the EFOP-3.6.3VEKOP-16-2017-00008 project. The project is cofinanced by the European Union and the European Social Fund.

\section{REFERENCES}

Abelho, M. (2008): Effects of leaf litter species on macroinvertebrate colonization during decomposition in a Portuguese stream. International Review of Hydrobiology. 93. 358-371.

Baldy, V.-Gessner, M. O.-Chauvet, E. (1995): Bacteria, Fungi and the Breakdown of Leaf Litter in a Large River. Oikos. 74. 1.93102 .

Bärlocher, F. (2005): Leaf Mass Loss Estimated by Litter Bag Technique. In: Graça M.A.S., Bärlocher F. and Gessner M.O., Eds., Methods to Study Litter Decomposition, a Practical Guide, Springer, Dordrecht, 37-42.

Boulton, A. J.-Bonn, P. I (1991): A review of methodology used to measure leaf litter decomposition in lotic environments: Time to turn over an old leaf? Australian Journal of Marine and Freshwater Research. 42.1. 1-43.

Chapman, S. K.-Koch, G. W. (2007): What type of diversity yields synergy during mixed litter decomposition in a natural forest ecosystem? Plant Soil. 299. 153-162.

Collier, K. J.-Winterburn, M. J. (1986): Processing of willow leaves in two suburban streams in Christchurch, New Zealand. New Zealand Journal of Marine and Freshwater Research. 20. 575582.

DIRECTIVE 2000/60/EC OF THE EUROPEAN PARLIAMENT AND OF THE COUNCIL of 23 October 2000 establishing a framework for Community action in the field of water policy. Official Journal of the European Communities.

Duarte, S.-Pascoal, C.-Cassio, F.-Bärlocher, F. (2006): Aquatic hyphomycete diversity and identity affect leaf litter decomposition in microcosms. Oceanologia. 147. 658-666.

Faye, L. M.-Beth, R. L.-Ormerod, S. J. (2006): The effects of low $\mathrm{pH}$ and palliative liming on beech litter decomposition in acidsensitive streams. Hydrobiologia. 571. 373-381.

Fisher, S. G.-Chauvet, E. (1973): Energy flow in Bear Brook, New Hampshire: an integrative approach to stream ecosystem metabolism. Ecological Monographs. 43. 421-439.

Gartner, T. B.-Cardon, Z. G. (2004): Decomposition dynamics in mixed-species leaf litter. Oikos. 104. 230-246.

Gaudet, J. J.- Muthuri, F. M. (1981): Nutrient relationships in shallow water in an African lake, Lake Naivasha. Oecologia. 49. 109-118.

Jenny, H.-Gessel, S. P.-Bingham, F. T. (1949): Comparative study of decomposition rates in temperate and tropical regions. Soil Sci. 68. 419-432.

Kallis, G.-Butler, D. (2001): The EU water framework directive: measures and implications. Water Policy. 3/2. 125-142.
Kominoski, J. S.-Pringle, C. M.-Ball, B. A.-Bradford, M. A.Coleman, D. C.-Hall, D. B.-Hunter, M. D. (2007): Nonadditive effects of leaf-litter species diversity on breakdown dynamics in a detritus-based stream. Ecology. 88. 1167-1176.

Melillo, J. M.-Naiman, R. J.-Aber, J. D.-Linkins, A. E. (1984): Factors controlling mass loss and nitrogen dynamics on plant litter decaying in northern streams. Bulletin of Marine Science. 35. 342-356.

Mutch, R. A.-Davies, R. W. (1984): Processing of willow leaves in two Alberta Rocky Mountain streams. Ecography. 7.2. 171-176.

Olson, J. S. (1963): Energy storage and the balance of producers and decomposers in ecological systems. Ecology. 44. 322-331.

Parsons, W. F. J.-Taylor, B. R.-Parkinson, D. (1990): Canadian Journal of Forest Research. 20. 7. 943-951.

Petersen, R. C.-Cummins, K. W. (1974): Leaf processing in woodland stream. Freshwater Biology. 4. 343-368.

Pozo, J. (1993): Leaf litter processing of alder and eucalyptus in the Agüera stream system (North Spain). I. Chemical changes. Archiv für Hydrobiologie. 127. 299-317.

Reddy, K. R.-Sacco, P. D. (1981): Decomposition of water hyacinth in agricultural drainage water. Journal of Environmental Quality. 10. $228-234$.

Schädler, M.-Brandl, R. (2005): Do invertebrate decomposers affect the disappearance rate of litter mixtures? Soil Biology and Biochemistry. 37. 329-337.

Smith, V. C.-Bradford, M. A. (2003): Do non-additive effects on decomposition in litter-mix experiments result from differences in resource quality between litters? Oikos. 102. 235-242.

Suberkropp, K.-Klug, M. (1976): Fungi and bacteria associated with leaves during processing in a woodland stream. Ecology 57. 707719.

Tardif, A.-Shipley, B. (2014): The relationship between functional dispersion of mixed-species leaf litter mixtures and species' interactions during decomposition. Oikos 000. 001-008.

Webster, J.-Benfield, E. (1986): Vascular plant breakdown in freshwater ecosystems. Annual Review of Ecological Systems. 17. 567-594. 